\title{
University Students' Attitudes towards Genetic Testing: A Comparative Study
}

\author{
Merav Siani*, Orit Ben-Zvi Assaraf \\ Science and Technology Education Department, Ben-Gurion University of the Negev, Be'er-Sheva8410501, Israel \\ *Corresponding author: sianim@post.bgu.ac.il
}

Received March 18, 2015; Revised March 25, 2015; Accepted April 01, 2015

\begin{abstract}
Background: Genetic counseling has become a tool for preventing genetic diseases in western society. It deals with the risk of genetic diseases in families and finds ways to prevent future problems. The public's decision making regarding genetic counseling is influenced by cognitive, cultural and religious variables. Aim and objectives: To examine the attitudes of undergraduate Israeli students toward genetic issues and learn how these are affected by the field they study, their religious affiliation and their gender. Methods: We gave 490 students a Likert type quantitative questionnaire consisting of several genetic cases, and asked the students to express their attitudes towards each one. Results and conclusion: Of the three factors we assessed, the most influential is the students' religious affiliation. Religious students, especially those who do not study life sciences (LS), place less trust in genetic tests than secular students $(\mathrm{p}=0.0001)$. Students of LS show more critical thinking towards genetic testing than others ( $\mathrm{p}=0.0128$ ). Gender was least influential, showing a mixed trend of influence. The results of this research can serve as a basis for developing culturally sensitive educational programs in genetics.
\end{abstract}

Keywords: genetic counseling, attitudes, quantitative assessment, genetic testing, undergraduate students

Cite This Article: Merav Siani, and Orit Ben-Zvi Assaraf, "University Students' Attitudes towards Genetic Testing: A Comparative Study.” American Journal of Public Health Research, vol. 3, no. 3 (2015): 81-90. doi: 10.12691/ajphr-3-3-1.

\section{Introduction}

Genetic counseling is part of the domain of health, providing citizens with personalized help regarding their own and their family's genetic health. It helps lay people understand complex genetic information, and thus make more informed personal decisions [1]. The informed decisions involving genetic risks that are dealt with in genetic counseling usually revolve around family planning and reproduction, decisions like whether to take a chance and bear a child in view of increased genetic risks, whether to use prenatal diagnosis, whether to continue a pregnancy when test results are positive or inconclusive, and what protective or preparative measures to take in the event of an increased risk to the fetus [2]. Informed decisions are decisions that are based on relevant information, consistent with the decision makers' values and applied in their behavior [3]. This means that cultural factors have great influence in the decision making process, especially regarding genetic testing $[4,5]$.

With the scientific and the genetic progress of the last three decades, genetic diseases can now be detected before or during pregnancy, which can drastically reduce the rates of hereditary diseases, and which makes genetic counseling an essential domain in every society. And yet, the willingness to receive counseling and genetic testing is not always common in every society, and is influenced by the individual's cultural background [6,7,8]. Because our society is culturally diverse, genetic counselors are expected to encourage people to make decisions that reflect their own personal and cultural beliefs, attitudes and values [1].

With this goal in mind, our study focuses on the attitudes of culturally diverse undergraduate Israeli students to genetic tests and to genetic counseling and looks at how these attitudes are influenced by three key factors - knowledge of genetics, religious belief and gender. Our working definition for the term attitudes is: a person's general feeling of 'favorableness' or 'unfavorable-ness' towards a given concept [9]. In this case our focus is on the feelings, beliefs and values our subjects express about genetics, genetics-related situations, or the impact of genetics on society.

Understanding the potential impact of such factors is important because this information can help us understand the process of decision making undergone by subjects of genetic counseling. Recently it has become clear that the evaluation of genetic knowledge and attitudes is an essential issue to investigate [10], but research about how different audiences react to and use genomic risk information is still scarce [11]. Although several studies have been done over the years that evaluate the knowledge of undergraduate students, $[12,13,14,15,16]$, along with several others that focus on the responses of students to receiving information about genetic diseases $[17,18,19]$, little attention has been directed to matching genetic information to the literacy levels of target audiences [20]. Receiving genetic information can lead to the enhancement 
of the students' genetic literacy (defined as 'sufficient knowledge and appreciation of genetics principles') and promote informed decision-making on genetic issues [13]. Our study's main objective is to shed light on attitudes toward genetic issues (with an emphasis on genetic counseling), amongst the adult population in Israel, which is represented here by undergraduate Israeli students. In order to reveal the main issues that influence these attitudes, we interviewed genetic counselors and senior geneticists throughout Israel who raised the problems that they face when meeting patients for counseling sessions. We interviewed experts from a variety of sectors working in hospitals and clinics throughout the country, so as to gain insight into the full range of their experiencein different sectors of Israel's highly diverse society. These experts are in a position to understand what the lay public needs in order to deal with the genetic information available today. They spoke about the lack of genetic knowledge with which they have to deal and the barriers to accepting genetic information they encounter, especially among religious sectors of the population. The need for more scientific information [21], positive attitudes towards genetic testing [22] and religious belief $[22,23,24]$ have been previously identified separately as predictors of the intention to undergo genetic testing and genetic counseling. Based on this information, we decided to examine the relationships between knowledge and attitudes, and how they are expressed differently in people from different religious backgrounds. The attitudes of our study population are therefore evaluated in correlation to the students' field of study, their religious affiliation and their gender.

Our study focuses specifically on undergraduate students because they are at the relevant age for genetic counseling concerning birth defects and genetic diseases. Beyond the fact that the discussion of topics such as newborn screening and prenatal testing is more appropriate for individuals of childbearing age [25], statistics show that in Israel most couples marry during their academic studies [26], and will hopefully have genetic counseling during those years. The undergraduate students' age is therefore the most relevant factor in our analysis of their genetic literacy.

\section{Methods and Materials}

\subsection{Goals and Research Questions}

Our goal was to examine the relationships between undergraduate students' attitudes regarding genetic dilemmas and their field of study, religious affiliation, and gender, and thus better understand how these factors impact decision making on genetic issues. We therefore composed a questionnaire that addresses three common topics in genetics and genetic testing and asked:

1. What are the attitudes of students towards the early detection of genetic diseases?

2. What are the attitudes of students towards decision making concerning late-onset diseases?

3. What are the attitudes of students towards examining the fetus for genetic disorders?

\subsection{Study Design and Population}

Our study population was composed of undergraduate students from a variety of higher education institutes throughout Israel. We focused specifically on undergraduate students because they are at the relevant age for genetic counseling concerning birth defects and genetic diseases. Our goal in constructing the sample was to achieve a large enough sample of each of our six basic categories (i.e. religious students vs. non-religious ones, life-science studiers vs. non-life-science studiers, male vs. female students) to perform statistical analysis, and for each category to contain roughly the same amount of students. We therefore appealed by email to higher education lecturers in all subjects that are studied at universities at the beginning of the 2013 academic year. With those who were willing to allow us to distribute the questionnaire, we arranged a mutually convenient time during the semester to come to their class and distribute our questionnaire. The students were told that the questionnaire was non-mandatory, that their answers were confidential and that its findings would be used for research purposes only. Completing it took approximately 30 minutes, and was done during the lesson, with one of the researchers present to answer questions.

We continued to administer the questionnaire and collect data throughout the 2013 academic year until we achieved a sample that we judged to be sufficiently large and balanced. The final sample consisted of 490 Israeli undergraduates, $73 \%$ of whom study in universities and the rest in colleges. $57 \%$ of the students were female, the rest male; $51 \%$ identified themselves as religious or semireligious and the rest were secular. 54\% studied life sciences (LS) and the rest studied subjects with no connection to genetics, such as economics, education or computer engineering.

One important limitation to note in our sample is that it does not include students from Israel's non-Jewish population, which includes Christian and Moslem Arabs, Druze, and Bedouins. Of the students who answered our questionnaire, only 3\% identified themselves as nonJewish, a percentage far too small to produce accurate results.

\subsection{Research Tool}

Ourresearch tool (Appendix 1) was a Likert-type questionnaire that we developed specifically for this study based on the literature review and in-depth interviews with genetics experts, all of whom have doctorates and most of whom are experts in prenatal genetic counseling at Israel's main hospitals. These resources raised issues such as: alternative conceptions concerning genetic tests and genetic diseases amongst the lay public, the layperson's difficulty in making informed choices on medical genetic issues, typical cases being dealt with in genetic counseling sessions, barriers to obtaining genetic information faced by different sectors of society, and religious influences on ethical considerations concerning genetic testing and genetic diseases. The independent variables that the experts noted as the most influential on the public's genetic literacy are: former knowledge, religious affiliation and gender, so these are the variables we adopted for our study.

The questionnaire was composed of two sections: Section A, a short knowledge test, and Section B, which 
assessed the students' attitudes. Since genetic literacy requires genetic knowledge [12,27,28], Section A of the questionnaire is a knowledge test, consisting of 6 multiple choice questions that are part of the tool developed by Bowling et al. [12]. The questions were chosen from different concepts identified in the Bowling tool as central to genetic literacy. This part of the questionnaire is only intended to clarify the difference, if one exists, between the genetic knowledge of students studying and not studying life sciences.

Section $B$ consists of 3 parts, comprising the main portion of the tool. It includes 15 five-point Likert-type statements with a scale of temporal frequency ranging from 1 (strongly disagree) to 5 (strongly agree), so that a high score indicates more positive attitudes towards the genetic domain discussed, and a lower score reflects doubt or lower levels of trust. Part 1 of Section B is based partially on Morren et al. [28], parts 2 and 3 made use of ideas from Wert et al.[29] and the guide written by Dawson, Carson and Venville [30].

The full questionnaire is attached in Appendix 1.

Section B, Part 1: The 5 Likert type statements in Part 1 deal with attitudes towards early detection of genetic diseases. For example:

1. I agree to take DNA tests intended for early detection of diseases, even if there is no treatment for these diseases yet.

2. I would inform my brothers and sisters of a DNA test result indicating I carry an inherited disease.

Section B, Part 2: The 3 Likert type statements here deal with attitudes towards late-onset diseases. Examples:

7. There is no reason to check for the gene for [Huntington's] disease. If the person gets sick, they will be diagnosed in due time.

8. It is better that a person does not know whether he has the gene for [Huntington's] disease or not.

Section B, Part 3: These 7 Likert type statements deal with attitudes towards examining the fetus for genetic disorders. Examples:

10. There is no reason to examine genes for deafness in the embryonic stage, as this is an illness people can live with.

11. If the genetic examination discovers that the fetus is deaf, it is better to have an abortion.

\subsection{Data Analysis, Validity and Reliability of the Questionnaire}

To validate the questionnaire, it was examined by three genetics experts and an expert in science education. This validation assessed the suitability of the questions to the study's goals, the relevance of the questionnaire to the research questions and the questions' phrasing. As Glynn, Taasoobshirazi and Brickman [31] suggest, we promoted candid responses by assuring the students that their identities would remain confidential, after explaining that their responses will help science education researchers to better understand and improve genetic counseling.

To assure reliability of the questionnaire's quantitative part, the Likert type statements were analyzed by their Cronbach's alpha value [32]. The internal reliability of Section B showed an overall Cronbach's alphavalue of 0.79. Removal of any of the 15 items in the section had the effect of weakening internal reliability. Part 1 showed a Cronbach's alpha value of 0.72 and parts 2 and 3 each showed a value of 0.7 .

\subsection{Statistical Design}

The dependent variables in our analysis were the mean attitudes arising from the 3 parts of Section B. We performed a two-way ANOVA test to check whether there was a significant interaction between each two independent factors at a time - gender, religious affiliation and field of study. Two of the three factors - field of study (LS students vs non-LS students) and religious affiliation (religious vs secular) were found to be significant. The gender factor did not contribute to the differences between the students in parts 1 and 2, though it did contribute to the difference in attitudes towards fetus examination (part 3). We therefore did a separate analysis for male and female in part 3 only. Since the interaction factor was significant in most of the ANOVA results, we conducted a series of ttests between the 2 levels of each factor to determine the strength of that interaction.

\section{Results}

To start our inquiry, it was necessary to evaluate the undergraduates' genetic knowledge (Appendix 1, Section A). This was essential because our premise is that undergraduate students studying life sciences know more about genetics than other students. This premise proved true, as in all 6 multiple choice questions, those who do study life sciences showed significantly more knowledge. In 5 of the 6 questions the significance level was $\mathrm{p} \leq 0.001$, and in one question it was $\mathrm{p}<0.05$. Moreover, among the life science students, gender and religious affiliation did not significantly influence the students' knowledge.

Section B, which is divided into parts 1,2 and 3, evaluates the students' attitudes and is composed of three parts that make up a total of 15 Likert type statements:

1. Attitudes towards early detection of genetic diseases - (early detection).

2. Attitudes towards late-onset diseases- (late-onset diseases).

3. Attitudes towards examining the fetus for genetic disorders - (fetus examination).

A two-way ANOVA test was conducted to find differences among the students according to their religious belief and their field of study (Table 1). We checked the F value for each of the variables (i.e. the three genetic topics) separately, according to religious belief, field of study and the interaction between them.

The overall $\mathrm{F}$ was significant for two of the three variables (early detection and fetus examination). For lateonset diseases the $\mathrm{p}$ was a borderline value, but for all three variables the interaction effect (religion $\mathrm{X}$ studies) was significant.

\section{Part 1-Attitudes towards early detection of genetic diseases}

The Part 1 statements show a strong interaction $(F(1,439)=4.31(p=0.039))$ between the students' religious affiliation and their field of study (see Table 1). This is further illustrated in Figure 1, which shows the mean of the 'attitudes towards early detection of genetic diseases' 
for the 4 groups we compared (i.e. (LS students, non-LS students) X (religious, secular)).

Table 1. Two way ANOVA test results

\begin{tabular}{|l|c|c|c|c|}
\hline & Overall F & F(religious belief) & F(field of studies) & F -Interaction (religion X studies) \\
\hline Early detection & $9.34^{* * *}$ & $16.78^{* * *}$ & $6.92^{* *}$ & $4.31^{*}$ \\
\hline Late-onset diseases & $2.48^{\mathrm{a}}$ & 1.51 & 1.84 & $4.09^{*}$ \\
\hline Fetus examination $^{\mathrm{b}}$ & $15.4^{* * *}$ & $31.98^{* * *}$ & 0.14 & $14.09^{* * *}$ \\
\hline Fetus examination, Women & $8.53^{* * *}$ & $9.24^{* *}$ & 0.80 & $15.56^{* * *}$ \\
\hline Fetus examination, Men & $9.74^{* * *}$ & $28.64^{* * *}$ & 0.55 & 0.04 \\
\hline
\end{tabular}

a: $\mathrm{p}=0.061$, a borderline value.

b: Including men and women

$0.050 .01<* \mathrm{p}<$

$0.001<* * \mathrm{p}<0.01$

$* * * \mathrm{p}<0.001$



Figure 1. Mean of the Part 1 statements dealing with 'attitudes towards early detection of genetic diseases' for the 4 groups we compared (i.e. (LS students, non-LS students) X (religious, secular))

The secular students (both LS and non-LS) scored highest, without differing strongly between them in their overall attitude towards early detection. Among the religious students, the LS students were very close to the secular students, while the attitudes of those who did not study LS were less positive. This was evident in the T-test results, which showed a significant difference amongst religious students between those who study LS and those who do not $(\mathrm{t}(218)=3.15, \mathrm{p}=0.0019)$, indicating that religious students who do not study LS have less trust in using genetic tests to detect genetic diseases at an early stage. Another significant difference was found between the religious and secular non-LS students $(\mathrm{t}(203)=3.22$, $\mathrm{p}=0.0015$ ), in which the secular students were more willing to acquire information about genetic tests and genetic diseases at an early stage $(\mathrm{M}=3.88 \pm 0.66)$ than religious students ( $\mathrm{M}=3.52 \pm 0.76)$.

\section{Part 2 - Attitudes towards late-onset diseases}

Figure 2 shows the mean of the 'attitudes towards lateonset diseases' for the 4 groups we compared (i.e. (LS students, non-LS students) X (religious, secular)).

The results for this part of the questionnaire showed no significant differences among the 4 groups of students. They showed very little difference amongst secular students between those who do and do not study LS. However, we did find a significant difference $(\mathrm{t}(236)=2.36$, $\mathrm{p}=0.019)$ between religious LS-students $(\mathrm{M}=3.58$ $\mathrm{SD} \pm 0.88)$ and religious non-LS students $(\mathrm{M}=3.28$ $\mathrm{SD} \pm 0.96$ ), which showed, like the results of Part 1 , that the religious students who do not study LS are less willing to receive genetic information.

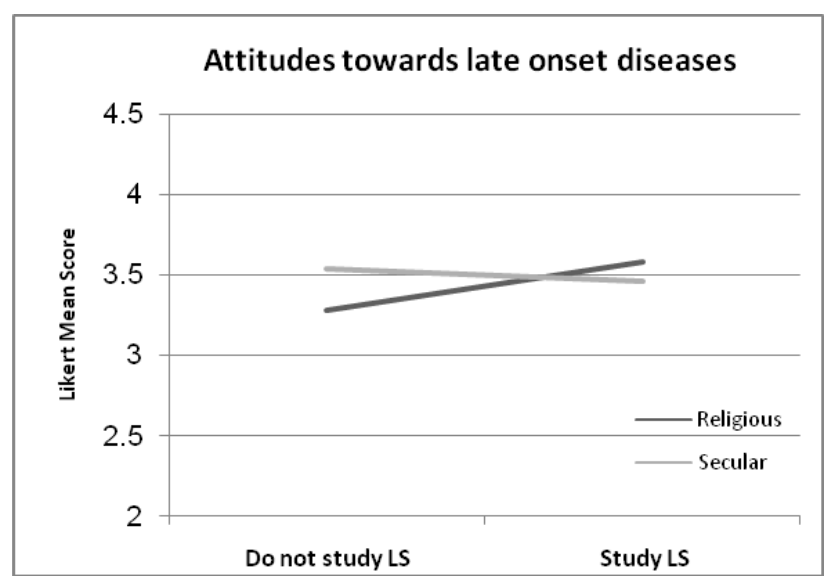

Figure 2. Mean of the Part 2 statements dealing with 'attitudes towards late-onset diseases' for the 4 groups we compared. (i.e. (LS students, non-LS students) X (religious, secular))

Part 3 -Attitudes towards examining the fetus for genetic disorders

The results for Part 3 showed an even stronger interaction between religious belief and field of studies $((F(1,463)=14.09 \quad(p<0.0001) \quad$ (see Table 1). Figure 3 illustrates the mean of the 'attitudes towards examining the fetus for genetic disorders' for the 4 groups we compared (i.e. (LS students, non-LS students) X (religious, secular)).

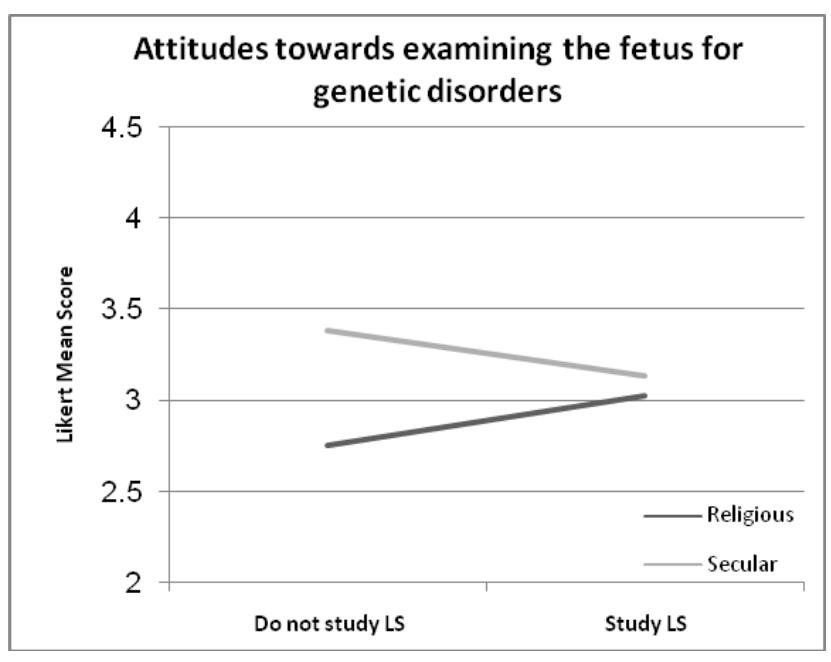

Figure 3. Mean of the part 3 statements dealing with 'attitudes towards examining the fetus for genetic disorders' for the 4 groups we compared (i.e. (LS students, non-LS students) X (religious, secular)) 
On this topic the secular students (both LS and non-LS) scored highest, though there was very little difference among the LS students between the religious and secular students. Amongst the secular students, those who do not study LS showed a more positive attitude towards examining the fetus $(\mathrm{M}=3.39 \pm 0.61)$ than those who do study LS $(M=3.14 \pm 0.7)$, with a high correlation $(\mathrm{t}(230)=$ $2.51(\mathrm{p}=0.0128)$ ), as seen in Figure 3. Surprisingly, this result is the opposite of the trend we had seen until now, suggesting that the LS students may be more critical to performing tests that can endanger the fetus. Amongst the religious students, we found a trend similar to that we had seen in parts 1 and 2: a significant difference between the LS students and the non-LS students $(\mathrm{t}(233)=2.81$ $\mathrm{p}=0.0054$ ), with religious non-learners of LS less willing to take risks in assessing the fetus $(M=2.76 \pm 0.72)$ than religious students who do learn LS (M=3.03 \pm 0.62$)$.

Of the three topics in our questionnaire, this was the only for which the gender factor contributed to the differences between the students. We therefore also included a separate analysis for men and women to determine the interactions between religious belief, field of study and gender in attitudes towards fetus examination (see Table 1).

Figure 4 shows the mean of the 'attitudes towards examining the fetus for genetic disorders' amongst male students in the 4 groups we compared (i.e. (LS students, non-LS students) X (religious, secular)).

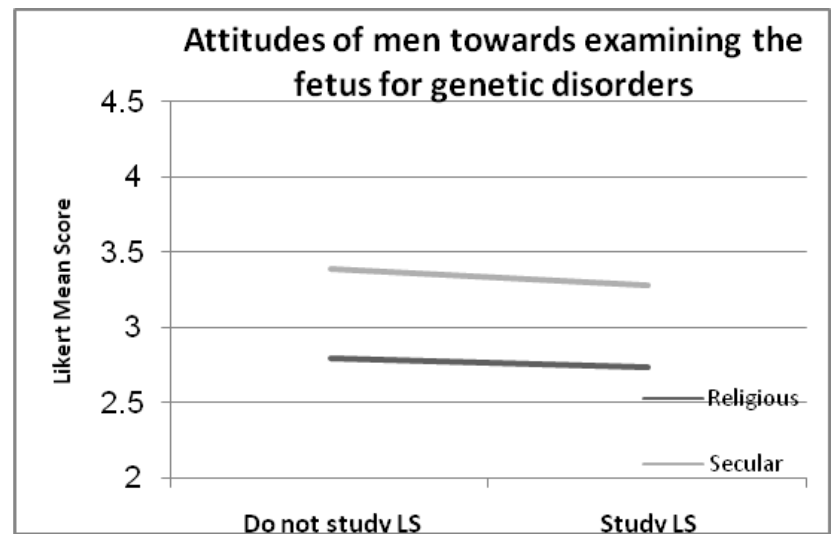

Figure 4. Mean of men's attitudes in Part 3 statements dealing with 'attitudes towards examining the fetus for genetic disorders' for the 4 groups we compared (i.e. (LS students, non-LS students) X (religious, secular))

There is a significant difference between the attitudes of the secular and religious men regarding the examination of the fetus for genetic disorders $(F(1,197)=28.64, \mathrm{p}<0.0001)$ (see Table 1). The secular students, both LS and non-LS, produced higher attitude scores than the religious students.

Among women, a strong interaction can be seen between religious affiliation and field of studies $((\mathrm{F}(1,255)=15.56 \quad(\mathrm{p}=0.0001) \quad$ (see Table 1$)$. Figure 5 shows this interaction, and presents the mean of the 'attitudes towards examining the fetus for genetic disorders' for female students in the 4 groups we compared (i.e. (LS students, non-LS students) X (religious, secular)).

The secular female students (both LS students and nonLS students) scored highest in their attitudes towards examination of the fetus. There was no difference for the female LS students between the religious and the secular students, but all the other comparisons showed significant results. As seen in Figure 5, a comparison between the LS and the non-LS female secular students $(\mathrm{t}(137)=2.39$ $\mathrm{p}=0.0183$ ), shows that studiers of LS scored less than nonstudiers, indicating they are more critical towards genetic tests that might risk the fetus. Comparison of the female religious LS students $(M=3.09 \pm 0.65)$ and non-LS students $(\mathrm{M}=2.68 \pm 0.72)$ shows a significant difference $(\mathrm{t}(118)=3.22$ $\mathrm{p}=0.0016$ ) that indicates even less trust amongst the non LS religious women to genetic tests that might risk their fetus. This tendency can also be seen between secular and religious non-LS students, where we see significant differences in their willingness to risk the fetus $(\mathrm{t}(91)=4.74 \mathrm{p}=0.0001)$.

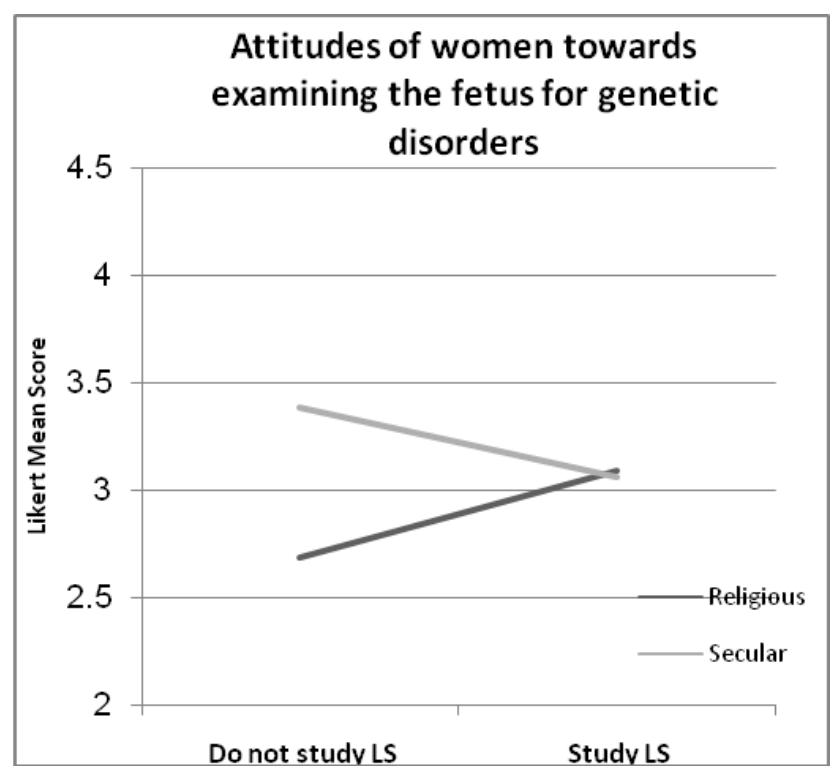

Figure 5. Mean of the women's attitudes in Part 3 statements dealing with 'attitudes towards examining the fetus for genetic disorders' for the 4 groups we compared (i.e. (LS students, non-LS students) X (religious, secular))

\section{Discussion}

The goal of this study was to probe the attitudes of Israeli undergraduate students towards genetic issues and discover how these are affected by their field of study, their religious beliefs and their gender. The study focuses on religious and secular Jewish students, some of whom study life science and have a firm genetic education background, while others study subjects with no connection to genetics and therefore have less genetic knowledge or none. We analyzed our subjects' perceptions towards three aspects of genetic testing. These perceptions can serve as indicators of the students' genetic literacy and of their willingness to perform genetic tests, and may also be predictors for their future behavior.

The main finding of the first research question, which addressed students' attitudes to the early detection of genetic diseases, suggests that the students' religion was an influential factor on how their previous knowledge of genetics affected their attitudes. In religious students, the effect of the knowledge is far more substantial, and it was an acute indicator amongst the religious members of our study population for more positive attitudes towards genetic tests. On the other hand, among the secular students, whose attitudes were more positive from the start, 
the fact that they study life sciences did not significantly alter their genetic attitudes in the field of early detection of genetic diseases. This means that among those who lack genetic knowledge, religiosity may be a crucial barrier for positive genetic attitudes. Studies of religious populations in other countries have yielded similar results. For example, in a study that compared African-Americans and Latinos with the same understanding of genetic testing who identified themselves as religiously committed, religion was a significant predictor for negative attitudes towards genetic testing [33] and towards science [34].

The second research question deals with late-onset diseases, diseases that are revealed at a late stage of life and allow good health for approximately 40 years, which raises controversial questions regarding whether it is better to be checked for them or not to know that you have the diseases at all. Our findings revealed that among religious students, knowledge of genetics is an important factor in determining positive attitudes towards running genetic tests for late onset diseases. It may be that students who study life sciences and know more about these tests and diseases have a more positive attitude to having the tests because knowledge reduces uncertainty and provides an opportunity for appropriate planning, even in cases when one knows that one is at higher risk for the disease. The influence of knowledge [35] as well as religious affiliation [36] have been previously shown in regard to Huntington's disease, one of the known late onset diseases and the disease addressed explicitly in our questionnaire.

The third research question deals with the examination of the fetus for genetic disorders, a controversial issue since this examination might lead to an abortion. The examination can reveal diseases of varying severity, giving rise to a range of family dilemmas. As seen in the first two research questions, here too the attitudes of the religious students who study life sciences tended to be more positive. Previous studies have shown that there is not always an exact correlation between belief and behavior, and that often the decision-making of a religious person regarding the testing of the fetus differs from the official religious stance [37]. Our results also suggest that individuals' background, including their previous or current studies, can sometimes influence their attitudes even more than their religious beliefs. Despite this caveat, religious belief does seem to have a significant influence on students' decision-making, since religious believers throughout the world believe that a Higher Power causes congenital problems or the loss of a pregnancy [24].

An interesting innovation found in the students' attitudes towards examining the fetus for genetic disorders is that it is among the secular students who do not study life sciences that the attitudes towards genetic testing were most positive, more than among all the other subpopulations tested. This finding can be a reflection of their desire to have an 'ideal' child, a phenomenon that has been noted among secular educated women in Israel, who choose to perform prenatal genetic diagnosis because of their fear of having a sick and/or socially unfit child in an unsupportive environment [38].

The fact that secular students of life science were less willing to undertake genetic testing than their non-life science studying counterparts implies that the addition of genetic knowledge may enhance the students' critical thinking towards genetic procedures, since in several cases some of the genetic tests may be unnecessary and even useless for part of the population. The critical thinking needed in this case is that of analyzing and evaluating the information [39], examining and querying the evidence, assessing the information about different genetic tests, and subsequently making informed decisions regarding whether to take these tests or not. Our claim that the additional genetic knowledge develops critical thinking has been shown in previous cases, which showed that though more knowledge of genetic testing raises enthusiasm for genetic testing, it also makes people wary of performing too many genetic tests [40]. All these imply that better knowledge does not simply lead to a blind acceptance of genetic tests, but that it rather indicates a certain level of critical thinking towards the options with which one is confronted.

All three parts of the questionnaire indicated that religious LS learners show more positive attitudes towards genetic tests than religious students who do not study life sciences. We suggest two possible explanations for the differences between the religious groups:

1. Studying sciences exposes the learners to scientific knowledge, expanding their scope and enabling them to have more positive attitudes towards the scientific system. The question remains, why is this explanation not relevant for the secular students' attitudes?! Is studying sciences a more significant event for religious students than it is for students who are not religious?

2. Perhaps, a priori, the scientific perceptions of the religious students who study life sciences are different than those who do not study life sciences. Possibly, religious youths who are interested in science recognize the significance of scientific activity, and this leads to their increased trust in science. If they choose to study science in the university, this recognition is strengthened and the studying creates a feedback of positive attitudes towards scientific concepts. This means that their attitudes and perceptions were not altered because of their studies, but that they were more accepting of the scientific system to begin with, when they made their initial choice to study life sciences.

As we mentioned before, this research was conducted among Jewish Israeli students, and in Jewish tradition it is legitimate for a religious believer to study sciences. Maimonides notes the importance of observing nature as a way to reach an understanding of the Creator of the world, and a way to reach love of God (Basic Laws of Torah, Chapter B section B). Based on that fundamental value, Jewish philosophers over the last generations have reached a consensus that studying sciences does not contradict religion, but on the contrary, it enables Jewish believers to strengthen their belief by studying the wonders of creation and improve our world in scientific domains [41,42]. This gives Jewish religious people the legitimacy to study sciences, and once they do so, they probably have a tendency to express more trust in scientific concepts.

Of the three factors we traced in this research, it seems that the most influential factor is the students' religious belief. It is the factor that influences the students' attitudes, and can probably be a predictor for the genetic behavior and choices the students will exhibit in the relevant stage of life. It is therefore important to determine students' religious beliefs prior to genetic counseling or prior to 
intervention programs, in order to 'tailor' the genetic counseling appropriately. This supports previous findings, which have shown that emotion, religious and secular values and beliefs, and non-institutional knowledge, are all at the very core of public understanding of genetic testing [43]. The differences in attitude between the religious students who learn life sciences and those who do not are significant throughout the three domains of our research, and addressing them would therefore make any potential customized genetic counseling more precise.

The students' field of study is a domain that influences the attitudes of religious students in particular, and might also be a predictor for future actions among this sector. Our findings stress the need for the intense education of the religious sector in science, and particularly in genetics, so as to diffuse the negative attitudes and low levels of trust of non-scientifically educated religious students.

Of the three factors we examined, gender has the smallest influence on the students' attitudes, showing only a mixed trend of influence. The students' gender will therefore probably not be a reliable predictor for genetic behavior, and for the choices the students make in genetic situations. These findings support the fact that there has been a shift in the last few decades towards a more "liberal" view of gender roles in western countries, meaning that people are less likely to believe in the need for a sharp gender division, and are willing to grant a wider range of social choices for women [44] exhibiting more liberal attitudes towards gender roles [45]. That is probably why we cannot detect a certain trend or a strong gender influence on our students' attitudes towards genetic topics.

\subsection{Limitations of the Study}

The central limitation of this study is that, due to its limited scope, it is not representative of the full diversity of Israel's population. Using undergraduate students was a useful means of gathering data from a population of the appropriate age and of assessing the impact of genetic literacy on attitudes, but this choice necessarily limited the population in important ways. As we have already noted, this choice required us to exclude non-Jewish students from the sample, and it also meant that the study's scope excluded other sectors of Israel's population that tend to be underrepresented in higher education institutions (e.g. people from lower socioeconomic backgrounds).

The cultural diversity in the state of Israel is extremely high, since it is composed of individuals from multiple ethnic and cultural backgrounds that embrace a variety of religious, national and cultural identities. The Jewish sector itself is divided into multiple religious and cultural sub-groups ranging from "secular" to "semireligious/traditional" to "national-religious" to "ultrareligious," divisions which can translate into extreme diversity in values, education and daily practices/behavior. Israel's non-Jewish minority groups incorporate an additional complex diversity into its population, differing significantly not just from the already diverse Jewish population, but from one another as well.

Properly and fully addressing all of these groups' relationships with genetic counseling is extremely important, but beyond the scope of our study. Our limited venture is only the first step towards gathering the information necessary to fully understand and address the needs of everyone who can and should benefit from the advantages of genetic counseling.

\section{Acknowledgements}

The authors would like to thank all respondents for their willingness and consent to participate in the study. We would also like to acknowledge the lecturers who were willing to enable us to distribute the questionnaire in their classes.

\section{Competing Interests}

The authors hereby declare that there was no competing interest in this study.

\section{List of Abbreviations}

LS-Life Sciences.

\section{References}

[1] National Society of Genetic Counselors [NSGC]: Available at http://www.nsgc.org.and accessed in 6/5/2014.

[2] Shiloh, S. (1996) Decision-making in the context of genetic risk, in: T. Marteu\& M. Richards(Eds) The Troubled Helix: social and psychological implications of the new human genetics. Cambridge University Press, Cambridge, UK.

[3] Marteau, T.M., Dormandy, E., Michie, S. (2001). A measure of informed choice. Health Expectations, 4:99-108.

[4] Awwad, R., McCarthy, V. P., Bartels D.M., LeRoy B.S.,(2008). Culture and Acculturation Influences on Palestinian Perceptions of Prenatal Genetic Counseling. Genetic Counseling, 17:101-116.

[5] Sterling, R., Henderson, G. E., \&Corbie-Smith, G. (2006). Public willingness to participate in and public opinions about genetic variation research: a review of the literature. American Journal of Public Health, 96(11), 1971-1978.

[6] Raz, A. E., \&Atar, M. (2003). Nondirectiveness and its lay interpretations: the effect of counseling style, ethnicity and culture on attitudes towards genetic counseling among Jewish and Bedouin respondents in Israel. Journal of Genetic Counseling, 12(4), 313-332.

[7] Shaw, A. (2011). Risk and reproductive decisions: British Pakistani couples' responses to genetic counselling. Social Science \& Medicine, 73(1), 111-120.

[8] Ten Have, H. (2001). Genetics and culture: The geneticization thesis Medicine, Health Care and Philosophy, 4: 295-304.

[9] Ajzen I., Fishbein M. (1980) Understanding Attitudes and Predicting Social Behavior. Prentice Hall, Englewood Cliffs, NJ.

[10] Christensen, K. D., Jayaratne, T. E., Roberts, J. S., Kardia, S. L. R., \& Petty, E. M. (2010). Understandings of basic genetics in the United States: results from a national survey of black and white men and women. Public health genomics, 13(7-8), 467-476.

[11] Lea, D. H., Kaphingst, K. A., Bowen, D., Lipkus, I., \& Hadley, D. W. (2010). Communicating genetic and genomic information: health literacy and numeracy considerations. Public health genomics, 14(4-5), 279-289.

[12] Bowling, B.V., Acra, E.E., Wang, L., Myers, M.F., Dean, G.E., Markle, G.C., Huether, C.A., (2008a). Development and evaluation of a genetics literacy assessment instrument for undergraduates. Genetics, 178:15-22.

[13] Bowling, B.V., Huether, C.A., Wang, L., Myers, M.F., Markle, G.C., Dean, G,E \& Jacob, G.A. (2008b). Genetic literacy of undergraduate non-science majors and the impact of introductory biology and genetics courses. BioScience, 58: 654-660.

[14] Fagen, A. P. (2003). Assessing and enhancing the introductory science course in physics and biology: Peer instruction, classroom 
demonstrations, and genetics vocabulary (Doctoral dissertation, Harvard University, Massachusetts.).

[15] Marbach-Ad, G., \&Stavy, R. (2000). Students' cellular and molecular explanations of genetic phenomena. Journal of Biological Education, 34(4), 200-205.

[16] Smith, M. K., Wood, W. B., \& Knight, J. K. (2008). The genetics concept assessment: a new concept inventory for gauging student understanding of genetics. CBE-Life Sciences Education, 7(4), 422-43.

[17] Falcone, D. C., Wood, E. M., Xie, S. X., Siderowf, A., \& Van Deerlin, V. M. (2011). Genetic testing and Parkinson disease: assessment of patient knowledge, attitudes, and interest. Journal of genetic counseling, 20(4), 384-395.

[18] Klitzman, R.L., (2010). Misunderstandings Concerning Genetics Among Patients Confronting Genetic Disease. Journal of Genetic Counseling, 19: 430-446.

[19] Michie, S., Lester, K., Pinto, J., \&Marteau, T. M. (2005). Communicating risk information in genetic counseling: an observational study. Health education and behavior, 32(5), 589598.

[20] McBride C.M., Koehly L.M., Sanderson S.C., Kaphingst K.A. (2010) The behavioral response to personalized genetic information: will genetic risk profiles motivate individuals and families to choose more healthful behaviors? Annual Review of Public Health. 31:89-103.

[21] Catz D.S., Green N.S., Tobin J.N., Lloyd- Puryear M.A., Kyler P., Umemoto A., ...Wolman F. (2005). Attitudes about genetics in underserved, culturally diverse populations. Community Genetics 2005; 8:161-172.

[22] Pivetti, M., \&Melotti, G. (2013). Prenatal genetic testing: An investigation of determining factors affecting the decision-making process. Journal of Genetic Counseling, 22(1), 76-89.

[23] Aqueel, A.I. (2007). Islamic ethical framework for research into and prevention of genetic diseases. Nature Genetics, 39: 12931298.

[24] Shaw, A. \& Hurst, J.A. (2008). "What is this Genetics, Anyway?" Understandings of genetics, illness causality and inheritance among British Pakistani users of genetic services. Journal of Genetic Counseling, 17:373-383.

[25] Long, K. A., Thomas, S. B., Grubs, R. E., Gettig, E. A., \&Krishnamurti, L. (2011). Attitudes and beliefs of AfricanAmericans toward genetics, genetic testing, and sickle cell disease education and awareness. Journal of genetic counseling, 20(6), 572-592.

[26] Central Bureau of Statistics [CBS], Israel. Available athttp://www.cbs , and accessed in 3/11/2013

[27] East, K. M., Hott, A. M., Callanan, N. P., \& Lamb, N. E. (2012). Biotech 101: an educational outreach program in genetics and biotechnology. Journal of genetic counseling, 21(5), 704-712.

[28] Morren, M., Rijken, M., Baanders, A. N., \&Bensing, J. (2007) Perceived genetic knowledge, attitudes towards genetic testing, and the relationship between these among patients with a chronic disease. Patient Education and Counseling, 65(2), 197-204.
[29] Wert, G. D., Meulen, R. T., Mordacci, R., \&Tallacchini, M (2003).Ethics and Genetics: A workbook for Practitioners and Students, Berghahn Books, New York.

[30] Dawson, V., Carson, K., \&Venville, G. (2009). Genetics education in the $21^{\text {st }}$ century, a guide for Australian high school teachers.

[31] Glynn, S. M., Taasoobshirazi, G., \& Brickman, P. (2009). Science motivation questionnaire: Construct validation with nonscience majors. Journal of Research in Science Teaching, 46(2), 127-146.

[32] Peterson, R. A., \& Kim, Y. (2013). On the relationship between coefficient alpha and composite reliability. Journal of Applied Psychology, 98(1), 194-198.

[33] Singer, E., Antonucci, T., \& Van Hoewyk, J. (2004). Racial and ethnic variations in knowledge and attitudes about genetic testing. Genetic Testing, 8(1), 31-43.

[34] Bauer, M. W., Allum, N., \& Miller, S. (2007). What can we learn from 25-years of PUS research? Liberating and expanding the agenda. Public Understanding of Science, 16(1), 79-95.

[35] Wiggins, S., Whyte, P., Huggins, M., Adam, S., Theilmann, J., Bloch, M., \& Hayden, M. R. (1992). The psychological consequences of predictive testing for Huntingtons disease. New England Journal of Medicine, 327(20), 1401-1405.

[36] Wit, A., Tibben, A., Duivenvoorden, H. J., Niermeijer, M. F., \&Passchier, J. (1998). Predicting adaptation to presymptomatic DNA testing for late onset disorders: Who will experience distress? Journal of medical genetics, 35(9), 745-754.

[37] Frumkin, A., Raz, A.E., Plesser-Duvdevani, M. \& Lieberman, S. (2011). "The Most Important Test You'll Ever Take"? Attitudes toward confidential carrier matching and open individual testing among modern-religious Jews in Israel. Social Science \& Medicine, 73: 1741-1747.

[38] Remennick, L. (2006). The quest for the perfect baby: why do Israeli women seek prenatal genetic testing? Sociology of Health and Illness, 28(1), 21-53.

[39] National Council for Excellence in Critical Thinking [NCECT]: Available at http://www.criticalthinking.org/ and accessed in 20/11/2014.

[40] Solli, A., Bach, F., \&Åkerman, B. (2014). Learning to argue as a biotechnologist: disprivileging opposition to genetically modified food. Cultural Studies of Science Education, 9(1), 1-23.

[41] Ruderman, D. B. (2001). Jewish thought and scientific discovery in early modern Europe. Wayne State University Press, MI.

[42] Soloveitchick, J. (1944) Ish ha-Halakhah, trans L. Kaplan, Halakhic Man. Jewish Publications Society, Philadelphia, PA.

[43] Doolin, B., \& Motion, J. (2010). Christian lay understandings of preimplantation genetic diagnosis. Public Understanding of Science, 19(6), 669-685.

[44] Inglehart, R. F. \& Norris, P. (2003). Rising tide: Gender equality and cultural change around the world. New York, NY: Cambridge University Press.

[45] Fodor, É.,\&Balogh, A. (2010). Back to the kitchen? Gender role attitudes in 13 East European countries. ZeitschriftfürFamilienforschung-Journal of Family Research, 22(3) 289-307.

\section{Appendix 1: Full Questionnaire}

\section{Information for research purposes:}

Academic institution

Course

Nationality: Jewish / Muslim / Christian

I describe myself as: ultra-orthodox/national religious / semi-religious / secular.

Gender: male / female

\section{Section A}
1. What is the relationship among genes, DNA, and chromosomes?
a. Genes are composed of DNA and lie within chromosomes.
b. Genes are separate entities from either DNA or chromosomes.
c. Genes are found only in chromosomes and not DNA.
d. Genes are found only in DNA and not chromosomes.
e. Chromosomes are composed of genes but not DNA. 
2. Adult height in humans is partially determined by our genes. When environmental conditions are held constant, humans have a wide variety of heights (not just short, medium, and tall). Height is probably influenced by:

a. one gene with two alleles.

b. a single recessive gene.

c. a single dominant gene.

d. several genes.

e. only paternal genes.

3. Molecular genetic engineering is possible

a. because all living organisms have the same DNA sequence.

b. because all living organisms have DNA as their genetic material.

c. because all living organisms have different but compatible structures of DNA.

d. because different genetic materials other than DNA are made compatible by scientists.

e. only among plant species or among animal species, but not between plants and animals.

4. Sometimes a trait seems to disappear in a family and then reappear in later generations. If neither parent has the trait, but some of the offspring do, what would you conclude about the inheritance of the trait?

a. Both parents are carriers of the recessive form of the gene.

b. Only one parent has two copies of the recessive form of the gene.

c. Only one of the parents has a dominant form of the gene.

d. Only one parent has a copy of the recessive form of the gene.

e. It is most likely the result of new mutations in each parent.

5. A woman has been told she carries a mutation associated with breast cancer. How does this influence her likelihood of developing breast cancer?

a. Her risk will be no different from any other healthy woman.

b. She will likely not get breast cancer.

c. She is at an increased risk for breast cancer.

d. She will definitely get breast cancer.

e. She already has breast cancer since she carries the mutated gene.

6. Cystic fibrosis (CF) is a recessive disorder, meaning that an individual must have two copies of an abnormal CF gene to be affected. What is the probability that a child of two individuals who each have one copy of the abnormal gene will be affected with CF?
a. $0 \%$
b. $25 \%$
c. $50 \%$
d. $66 \%$
e. $75 \%$

\section{Section B}

Part 1

In the following sections you should indicate the degree of agreement with the various statements.

Genetic research now allows early detection of diseases.

\begin{tabular}{|c|c|c|c|c|c|}
\hline & Strongly disagree & Disagree & Not sure & Agree & Strongly agree \\
\hline $\begin{array}{l}\text { 1. I agree to take DNA tests intended for early detection of } \\
\text { diseases, even if there is no treatment for these diseases yet. }\end{array}$ & & & & & \\
\hline $\begin{array}{l}\text { 2. I would inform my children about DNA test results for genetic } \\
\text { diseases I was tested for, when they are about to get married. }\end{array}$ & & & & & \\
\hline $\begin{array}{l}\text { 3. I would inform my brothers and sisters of a DNA test result } \\
\text { indicating I carry an inherited disease. }\end{array}$ & & & & & \\
\hline $\begin{array}{l}\text { 4. I would not want a genetic survey to inform me that I am at } \\
\text { risk for a genetic disease. }\end{array}$ & & & & & \\
\hline $\begin{array}{l}\text { 5. As long as there is no treatment for a disease, I do not want to } \\
\text { have a genetic test for that disease. }\end{array}$ & & & & & \\
\hline
\end{tabular}

\section{Part II}

Huntington's disease is a genetic disease caused by a dominant gene mutation. Symptoms begin in adults (usually from the age of 40. Until then there are no signs of illness). The disease is fatal after a period of suffering.

\begin{tabular}{|l|l|l|l|l|l|}
\hline & Strongly disagree & Disagree & Not sure & Agree & Strongly agree \\
\hline $\begin{array}{l}\text { 6. Every child should be examined for the disease } \\
\text { immediately upon birth. }\end{array}$ & & & & & \\
\hline $\begin{array}{l}\text { 7. There is no reason to check for the gene for this disease. } \\
\text { If the person gets sick, he will be diagnosed in due time. }\end{array}$ & & & & & \\
\hline $\begin{array}{l}\text { 8. It is preferable that a person does not know whether he } \\
\text { has the gene for this disease or not. }\end{array}$ & & & & & \\
\hline
\end{tabular}

\section{Part III}

\begin{tabular}{|l|l|l|l|l|l|}
\hline & Strongly disagree & Disagree & Not sure & Agree & Strongly agree \\
\hline $\begin{array}{l}\text { 9. In late onset diseases, such as Huntington's disease, the } \\
\text { disease should be examined prenatally. The fetus should } \\
\text { be examined in amniocentesis, even if the examination } \\
\text { endangers the pregnancy. }\end{array}$ & & & & & \\
\hline
\end{tabular}

Deafness is a syndrome that can be caused by mutations. It is now possible to examine a fetus prenatally for mutations causing deafness. 


\begin{tabular}{|l|l|l|l|l|l|}
\hline & Strongly disagree & Disagree & Not sure & Agree & Strongly agree \\
\hline $\begin{array}{l}\text { 10. There is no reason to examine genes for deafnessin } \\
\text { theembryonic stage, as this is an illness people can live } \\
\text { with. }\end{array}$ & & & & & \\
\hline $\begin{array}{l}\text { 11. If the genetic examination discovers that the fetus is } \\
\text { deaf, it is recommended to have an abortion. }\end{array}$ & & & & & \\
\hline $\begin{array}{l}\text { 12. The deafness genes should be examined and the family } \\
\text { should deal with the results per its discretion. }\end{array}$ & & & & & \\
\hline $\begin{array}{l}\text { 13. The state of Israel should not fund research dealing } \\
\text { with diseases such as deafness, which are not life- } \\
\text { threatening. }\end{array}$ & & & & & \\
\hline
\end{tabular}

Nowadays there is a method (PGD) enabling examination of an inherited disease existing in the family, in embryos in vitro, before their introduction into their mother's womb. In this method, only healthy embryos are inserted into the womb.

\begin{tabular}{|l|l|l|l|l|l|}
\hline & Strongly disagree & Disagree & Not sure & Agree & Strongly agree \\
\hline 14. I think such examinations have future ethical dangers. & & & & & \\
\hline $\begin{array}{l}\text { 15. Every available genetic examination should be } \\
\text { performed in the fetus, to rule out the maximal number of } \\
\text { diseases a child might be born with. }\end{array}$ & & & & & \\
\hline
\end{tabular}

